\title{
Celebrity meets Populism in Europe: The Political Performances of Nicolas Sarkozy and Silvio Berlusconi
}

\author{
Stephen Alomes
}

RMIT University

stephen.allomes@rmit.edu.au

\author{
Bruno Mascitelli \\ Swinburne University \\ bmascitelli@swin.edu.au
}

\begin{abstract}
Throughout the world, celebrity and populism have become formidable combinations in supporting political leadership. The rise of these phenomena has provoked much debate and has led to the examination of the features, causes and consequences of this kind of politics. Celebrity politics is a reflection of both the influence of celebrities and the power of celebrity images in the media which see politicians becoming celebrities, deliberately or accidentally. The political rise and fall of Nicholas Sarkozy and Silvio Berlusconi and their roles in the performances associated with political leadership furnish two case studies of celebrity and populism in France and Italy respectively. This paper examines these two "presidentialstyle" leaders in Europe who at first seemedadept in practising aspects of both celebrity and populist politics.
\end{abstract}

Key Words: celebrity, celebrity politics, populism, Sarkozy, Berlusconi, Europe.

\section{Introduction}

Celebrity politics has become a subject of debate across the globe. More prominent during the television era, the phenomenon reflects both the influence of celebrities and the power of celebrity images in the media. Politicians sometimes have to act and perform as celebrities. As one contemporary observer remarked, "For democracy, it is now universally acknowledged, obliges political leaders to be celebrities". ${ }^{1}$

'A. Perkins, 'The celebrity debasement of politics', The Guardian, London, 10 February 2010. 
This article focuses on celebrity politics, in which politicians seek celebrity status, and its recent coupling with populist styles of political performance. In the US, celebrity politics has emerged in moments of political vacuum and crisis and as a tool to enhance the electoral prospects of politicians. Prominent examples of this style of politics since "JFK" (John Fitzgerald Kennedy) have been Ronald Reagan, Bill Clinton and Barack Obama. ${ }^{2}$ In Europe, emerging in the post-Cold War political era, this is popularly depicted as the "Americanisation" of politics in Europe. 3 Several mainstream European political leaders have engaged in celebrity style politics to a degree, including Gerhard Schroder in Germany and Vladimir Putin in Russia. In the current era of political angst and of the rise of different forms of populism celebrity politics has become more prominent. This study focuses on two "presidentialstyle" leaders in Europe who practised aspects of both celebrity and populist politics, France's Nicolas Sarkozy and Italy's Silvio Berlusconi. It demonstrates how these leaders have approached celebrity and utilized celebrity status /to provide their own distinct form of leadership within their own national polities. It also evaluates their political performance in relation to marginal and mainstream populism in the current globalising era.

It remains in question whether celebrity status politics in Europe may be another step in the greater political alienation of the electorate. Has the media created an "imagined democracy" or "imagined polity"? The electronic and traditional "fourth estate" has become a new electorate, prioritising image over substance, even before the rise of the new media. Contemporary political performance demands new televisual forms of engagement, differing from traditional political structures and discourses. Simultaneously, changes in political culture are the product of our times, of Europe today, and also of distinct national political traditions.

\section{The Age of Celebrity}

Celebrity, which transcends earlier forms of fame or stardom, is usually defined as the status of someone who is, or has become, famous for being famous.4 Marshall argues that celebrities, via mass media, enjoy "a greater presence and wider scope of activity and agency than are those who make up the rest of the population. They are allowed to move on the public stage while the rest of us watch".5

The fame of a celebrity can acquire a life of its own which transcends the original reason for the fame. Heroes, valorised in the Victorian era and after, are now supplanted by celebrities. ${ }^{6}$ That achievement may have been in film, stage, music, sport, or other spheres entirely. It may also be due to acquired or inherited wealth, which brings with it a media profile (such as Paris Hilton),

2 D. West D. and J. Orman, Celebrity Politics, Englewood Cliffs, NJ, Prentice Hall, 2003.

3 The Economist, 'Celebrity politics, A new cult from America - French political families', December 9, 2004, The Economist, London, 2004.

4 D. J. Boorstin, The Image: or What Happened to the American Dream, Harmondsworth, Penguin, 1963, p.67.

5 P.D. Marshall, Celebrity and Power: Fame in Contemporary Culture, University of Minnesota Press, Minneapolis, USA., p.ix, 1997.

${ }^{6}$ S. Alomes, Australian Football The People's Game 1958-2058, Sydney, Walla Walla Press, 2012, pp. 76-80, 87-91. 
as in the old popular press formulation "the rich and famous", or profile or wealth through marriage (for example, Simone Callahan, ex-wife of celebrity cricketer, Shane Warne). While celebrity is a new form of cultural and social power, style and display have often been part of the public performance of the powerful. Machiavelli argued that the Prince had to use the "majesty" of the Royal Court and office to impress the people. 7 Burke explores a specific phenomenon in his book "The Fabrication of Louis XIV". ${ }^{8}$ Adolf Hitler's creation of the Führer's mythical status within the Nazi construction of the German tradition is a later example. The influence of celebrity today is reflected in changing aspirations of the young. The "career aspiration" to "become famous" has increasing popularity amongst children and adolescents, who aspire for fame rather than a specific achievement, as an avenue which might lead to fame.

\section{Politicians as Celebrities}

How then can a politician, who deals with practical legislative realities such as budgets and programs, taxes and laws, and gives long speeches, become a celebrity? Like a marketed brand or image, poltiticians become celebrities by association with the famous, through orchestrated brushes with fame, suggesting that the celebrity endorses the politician. Sometimes, their own modish style and personal charms enhance their image and their media profile. In the mass market of mass electoral politics, as political leaders are branded, marketed and sold like Weet-Bix, celebrities can also enhance the appeal of "the product". 9

Secondly, some individuals are recruited to politics because of their celebrity status and profile. Examples include the actors President Ronald Reagan, and Governor Arnold Schwarzenegger, and the professional wrestler Governor Jesse Ventura in the USA, rock singer Peter Garrett and former sports stars, Ric Charlesworth, Kirstie Marshall, Justin Madden and Darrel Baldock in Australia. "Celebrities are stepping in to the role of politicians and politicians are being packaged and presented increasingly as celebrities" 10 In a culture with more celebrities in film, television, music, fashion, sport and beyond, and more media gossip columns (in print, on television, on the web and now also the blogosphere, Facebook and the Twittersphere), and with movie stars no longer constricted by studio systems, celebrities are increasingly associated with political causes. ${ }^{11}$ Some, such as Oprah Winfrey and Donald Trump join television fame with real wealth, endorsing politicians (Oprah's 2007 support for Obama) or fantasising about political roles (Trump's 2011 presidential aspirations).

\footnotetext{
7 N. Machiavelli, (n.d) The Prince, Planet PDF,pp. 129, 133, 142 and 159.

8 P. Burke, Peter, The Fabrication of Louis XIV, New Haven, Yale University Press, 1994.

9 D. Marsh, D. P.'t Hart, P. and K. Tindal 'Celebrity Politics: The Politics of Late Modernity', Political Studies Review, Vol. 8, 2010; J. A. Morello, Selling the President, 1920: Albert D. Lasker, Advertising, and the Election of Warren G. Harding,Westport and London, Praeger, 2001; B. I. Newman, The Marketing of the President: Political Marketing as Campaign Strategy, Thousand Oaks, Sage, 1994. ${ }^{10}$ T. Weiskel, 'From Sidekick to Sideshow-Celebrity, Entertainment, and the Politics of Distraction', American Behavioral Scientist, November 2005, Vol. 49, No. 3, 2005, p.394.

${ }^{11}$ D. Drezner, 'Foreign Policy goes slam', The National Interest, IssueNovember-December 2007, 1 November 2007, UK, 2007.
} 
Thirdly, all political leaders become a celebrity because they are always in the public eye. Since the prime minister or president is always on television they become famous; in Australia, schoolchildren want to meet, and touch, them, often without any knowledge of their political party orientation, except that they are on television. ${ }^{12}$

In France, the president has long been a national figure, the embodiment of the nation, of "la gloire de la France" (the glory of the nation): "The king is dead/ Long live the king/emperor/president”. Arguably Napoleon was a successor to Louis XIV, the Sun King, in the great man as the personification of the state, and of France, even as the revolution and his empire challenged the past order, the ancien regime. That embodiment of the nation was exemplified in the persona of the President. In partial contrast, Sarkozy, embracing celebrity, flouted the French tradition that the private life of the President remained private. ${ }^{13}$

Celebrity repertoires, including dramatic gestures, staging photo opportunities at popular events and association with celebrities enhance the politician's media standing, and ideally their popularity as well as their profile. The personalisation or presidentialisation of politics, as contests between parties focus on the image of the leader, following the American model, reinforces this pattern for all political leaders. Some stylish, theatrical or dramatic individuals, including Nicolas Sarkozy and Silvio Berlusconi, have embraced the celebrity role. An election candidate's style can be as important as any political substance, as exhibited in the election of Barack Obama. Even cooler than Bill Clinton, he has been described as "the first pure celebrity presidential candidate”. In 2007-8, he was “...a superior celebrity, superbly in control of himself, masterful at presentation, effortlessly detached, as the best celebrities are, from the controversies that swirl around him”. ${ }^{14}$

\section{Celebrity and Populism}

The increasing role of celebrity in politics is not just a consequence of the contemporary era of celebrity culture. The political leader as celebrity has also become important because of the related phenomenon of celebrity or mainstream populism. ${ }^{15}$ Celebrity and populism share several characteristics, which differ from the specific content of political ideologiessuch as neo-liberal capitalism, socialism and communism. First, both celebrity and populism are empty vessels which can be filled in varying ways. A flood tide of predominantly extreme Right or marginal populism has emerged in Europe from Finland to Italy, and France to Eastern Europe, as well as in the USA, Australia, and, traditionally, South America. ${ }^{16}$ Significantly, it has been

\footnotetext{
12J. Chong, 'Howard hug ... with a twist', Sydney Morning Herald, 27 July, 2006.

${ }_{13}$ N. Hewlett, The Sarkozy Phenomenon, Exeter, Societas, 2011.

14 G. Sheridan, 'Politics of celebrity takes over', The Australian, 1 November 2008,

<http://www.theaustralian.com.au/news/politics-of-celebrity-takes-over/story-e6frg6v6-

$1111117913435>$, last accessed 11 July 2013.

${ }^{15}$ S. Alomes,(2012) 'Margins to Mainstream: Populism in Australia and Japan', in S. Alomes,

P.Eckersall, R.Mouer and A. Tokita (eds.) Outside Asia: Japanese and Australian Identities in Flux, Melbourne, University of Melbourne Custom Book Centre, 2012.

${ }^{16} \mathrm{G}$. Ionescu and E. Gellner, E. (eds.), Populism, London, Weidenfeld and Nicholson, 1969 pp.3-4, 166171; M. Canovan, Populism, New York: Harcourt Brace Jovanovich, 1981, pp.4-16; Y.Mény and Y. Surel,
} 
paralleled by mainstream or celebrity populism as practised by political leaders across several different political cultures. ${ }^{17}$

The populist leader and the celebrity share an idea of their elite role, as either would-be people's leader or as a "star". They understand the need to be noticed. In our image-driven society they want to be "looked at" via both old and new media. Therefore, they often indulge in photo opportunities or pursue stunts, actions in odd places, or make controversial or dramatic public statements, and now use social media such as Twitter. However, stunts and throwaway lines which keep the public interested can backfire. They can be seen as gaffes and indicators of political folly rather than consistency.

Politicians have found that "distracting" the electorate (aword once associated with divertissement or entertainment) diverts its attention from key issues as the audience consumes another story or vignette about the political leader. However, rapid shifts of policy and media stunts and verbal gestures can lead to the politician being labelled a "political opportunist", lacking clear policies, rigorous attention to detail and a capacity to implement policy. Sarkozy acquired this flighty profile as he jumped from one project to another, one media moment to another. The image of a frank, tough-talking political leader, with clear policies to take France out of its economic and social malaise, was replaced by the spectre of a small man with a larger than life attractive young wife. "M. le Président" was nowhere to be found.

Populism has flourished in difficult times - the globalising era characterised by dramatic structural change, demographic movements, political instability and political party convergence under neo-liberal political ideologies after the end of Communism. In this unsettled era, an anxious Europe fears the economic challenge of North East Asia and the ideological, immigration and terrorist "threat" associated with Islam. In response, many politicians play populist, and sometimes celebrity populist cards, as part of their electoral performance, as they seek to relate more closely to "the people", the voters. Celebrity populism has been used in different ways by Nicolas Sarkozy in France and Silvio Berlusconi in Italy.

\section{Defining Contemporary Populism's Varieties}

In Europe, unlike the Anglo-Saxon countries, celebrity politics has generally been adopted more by centre-right politicians rather than those of the centreleft, even as ideological distinctions decline. Clinton, Blair and Rudd contrast with Sarkozy and Berlusconi. In Europe, this is a recent phenomenon which appears to be ongoing. Several European marginal populist politicians have developed celebrity style, including the late Austrian Right politician Jorg Haider and Dutch anti-immigration party leaders, Pim Fortuyn and Geert Wilders. Along with Le Pen's Front National and Pauline Hanson's One Nation Party in Australia, these politicians have also influenced mainstream

(eds.) Democracies and the Populist Challenge, London, Palgrave, 2002.; H. Betz and C. Johnson, Against the current-stemming the tide: the nostalgic ideology of the contemporary radical populist right. Journal of Political Ideologies, Vol. 9, No.3, 2004, p.327.

${ }^{17} \mathrm{~S}$. Alomes, op. cit. 2012. 
agendas and the major parties' quests for electoral support, although this is beyond the focus of this article. Populism is not a simple synonym for popularity nor is it a reference to political leaders' inherent desire to be popular, despite journalists and arts reviewers' loose use of the term to connote all things popular. Populism varies according to place,time,society and culture and has historical antecedents and certain common if not always ubiquitous characteristics. Political populism is an omnibus which can be filled in different ways rather than a specific social ideology. In fact, it is often utilises class politics denuded of the formal concepts of class. Its characteristics are:

An emphasis on expressive emotions over instrumental political policies with clear results, expressing the frustrations and desires of the disempowered people, who feel themselves lacking in potency in contrast to the elites, who are seen as conspiring against them. ${ }^{18}$

A populist leader who is usually central. They seek to become the leader, the voice and the will of the people, the embodiment of their aspirations; a saviour, a charismatic leader (originally a religious term) promising to take them out of the wilderness. ${ }^{19}$ Such leaders can be central or marginal, successful or not, in different traditions, from General Peron in Argentina to Sarah Palin and the Tea Party in the USA and Pauline Hanson and her One Nation Party in Australia.

In Western history, populism was associated with marginal social-political movements, with a rural or working class sense of being dispossessed by urban or capitalist (and sometimes Jewish) elites. Traditionalist and nationalist, whether Left or Right, it promised redemption and renewal, in contrast to the perceived greed, vice and rule of the elites. Such themes were central in farmers' populism towards cities and bankers and in working class populism against rich elites in the USA and Australia, although, as in Europe, populism often had an anti-Semitic aspect.

Today, as Western societies face the stresses of globalisation, marginal populism is increasingly associated with extreme Right fringe parties which assert traditional nationalism as they oppose and condemn immigrants, multiculturalism and other religions, now Islam rather than Judaism. Fringe minority parties, often with popular names such as the Danish People's Party and the Austrian Freedom Party, can reshape politics by changing the terms of the debate or by forming coalitions with conservative mainstream parties. In Western Europe, they include the True Finns, and comparable parties in Sweden, Switzerland, the Netherlands, Italy (the Northern League, Lega Nord), France (Le Pen's Front National) and in Hungary.

The mainstreaming of populism, as it moves beyond the margins to focus on mainstream parties' leaders, has occurred in three ways. One is the changed political and social debates in the globalising world as the West confronts

${ }^{18}$ S. Alomes, “Past Caring”: Political Alienation and Populism in Australia and Beyond,' in D. Callahan, (ed.) Past Caring, Perth, API Network, 2007, pp. 289-90; Ionescu and Gellner, op.cit.

${ }^{19}$ M. Canovan, Populism, New York: Harcourt Brace Jovanovich, 1981, pp. 4-16, 268-9, 286-9. 
economic and cultural challenges. A second involves political leaders wanting to be popular, to be well-liked, to be a mirror reflecting the people while simultaneously being their leader, in a role that is more nuanced than simply being a figurehead for or a representative of an elite or a party. Finally, in this new context politicians use populist devices (maverick gestures, political stunts, prejudicial remarks, often then withdrawn or qualified) to maintain their own "theatrical profile" on the political stage. ${ }^{20}$

Winock argues that in France, historically, Right populism was based on three principal assertions: (1) that France was in a state of decadence and society was falling apart; (2) that a minority of maleficent agents was responsible for this decadence and that Jews played a central role in this "diabolical causality" ("everything comes back to the Jews"); and (3) that France would be saved from decadence by a providential man - whether at different times the proposed saviour was Georges Boulanger, Philippe Petain, or Jean-Marie Le Pen. ${ }^{21}$ In France, as in Italy, there are continuities, but also more importantly discontinuities with this inter-war heritage of Right populism ranging to extremism.

\section{Nicolas Sarkozy and French Celebrity Politics}

In 2004, several observers noted dramatic changes in French politics:

"... the intimate political marketing of families marks a new trend in French politics: in a word, Americanisation. It is not just that France's system has become more presidential since the term of a president was cut from seven years to five. It is also a matter of style. Mr Sarkozy's stage show, complete with giant images of him surrounded by adoring crowds, echoed American conventions. When he appeared on a chat-show, he naturally brought his then wife, Cécilia... Even French politicians, it seems, are ready to risk overexposure". ${ }^{22}$

Nicolas Sarkozy, small in stature, frenetic in movement and a descendant of Hungarian immigrants, while implementing populist "tough on immigrant" policies in government, challenged French political traditions. Although also a Gaullist, in the UMP party, he sported a flash style and flashier friends. He ushered France into the era of celebrity politics. His 2007 election as President generated enormous excitement at home and abroad as change was anticipated. Noted as an energetic, young, new brand of politician, Sarkozy campaigned on radical and heavily publicised centre-right "reforms" against the Socialist candidate Ségolène Royale, herself presented in image terms as a new "Madonna". Sarkozy spoke of a "rupture", a "clean break" with the past, and many believed that here was the candidate for real change. While he proposed a tough, neo-Thatcherist challenge to the size of the French state, Royale offered a kind of aesthetic Left charisma, different from the stonier male "elephants" of the Socialist Party. After the strong and decisive man defeated Royale, he employed a strategy of control, courting and mastery of the French media. One observer noted Sarkozy's approach, sometimes leading

${ }^{20}$ Alomes, 'Margins to Mainstream: Populism in Australia and Japan'. op. cit.

${ }^{21}$ M. Winock, Nationalism, Anti-Semitism, and Fascism in France, Stanford, California, Stanford

University Press, translated by Jane Marie Todd, 1998.

${ }^{22}$ The Economist, op. cit. 
to the sobriquet "hyperpresident", of seeking to be "hypervisible" even if his Presidency was not in fact "hyperactive". Sarkozy's first year in office was uneventful and with little to show for it. From late 2008, the global financial crisis torpedoed his neo-Thatcherite policies. Like many governments, his administration could not resist the Keynesian imperative towards fiscal stimulus rather than contraction.

Early in his presidency, the French public was subjected to an extraordinary series of soap operas. The president's highly publicized divorce was anything but private and new wife, singer and model Carla Bruni became a significant part of the "Sarkozy show", like a Jackie Kennedy to JFK. Stylish young women were also part of the Berlusconi celebrity show. Sarkozy made his lifestyle-a victory dinner at the expensive Fouquet's restaurant, followed by a succession of yacht trips, Ray-Bans, Rolexes and overseas vacations, often travelling in his millionaire business friends' executive jets or lazing on their yachts, the focus of his presidency 23 Sarkozy wanted the French people to know he was enjoying his role as president. However, as the French people struggled with a shrinking job market and rising prices, this ploy did not endear the leader to the nation. Nor were they unequivocally enthusiastic about his media magnate friends, including Francis Bouyges of Bouyges Telecoms.

From his earliest days in French politics Sarkozy was conscious of the importance of mastering the media. As Mayor of the Parisian suburb of Neuilly-sur-Seine, and later as a Minister, he sought ongoing media coverage. When a heavy-handed Minister of the Interior in 2005, meting out severe measures against criminality and immigrants, he made sure the media was reporting his side of the equation, his view of the events and of what was best for France. This was Sarkozy's way. It contrasted with the past, when a Minister of the Interior might seek a lower profile while controversial social and political measures were being enacted.

Sarkozy took up "jogging”, characterised by many French people as an American vice, and associated himself with film celebrities including Tom Cruise. In 2006-7, his candidature was endorsed by the black rapper Doc Gyneco and an ageing Johnny Hallyday, clad in a white suit, black sunglasses and "Johnny with Sarkozy" T-shirt. Sarkozy sought celebrity status through being seen with celebrities; he hoped to be "cool", modern and fashionable, and to be photographed or filmed with the right people. Sharing the French interest in reality television programs, he invited current celebrities for dinner.This role involved a sharp departure from the gravitas of the office displayed by previous Presidents, through the monumental solemnity of Charles de Gaulle, the intellectual loftiness exhibited by Valéry Giscard d'Estaing and François Mitterrand, and the less formal yet dignified detachment of Jacques Chirac. ${ }^{24}$ Until Sarkozy flouted national tradition, the private life of the President remained private, not a subject for media discussion or scandal, for example, Francois Mitterrand's mistress and his daughter. Under France's strict privacy laws, the affairs and indiscretions of

23 B. Crumley, Sarkozy's “Bling-Bling” Presidency, December 20, 2007, Time Magazine, USA.

24 Ibid. 
previous presidents were not public knowledge; nor were their private doings deemed relevant to their public role in government.

\section{"Président Bling Bling"}

M. Sarkozy began to lose his shine when some French commentators became irritated by his fusion of private life and public antics while in government. In December 2007 Libération published a feature on the "Bling Bling Président" 25 meaning someone obsessed with rendering public aspects of his private life, displayed in the public domain. Crumley noted:

Out are the days of sombre, aloof and understated figureheads of the French Republic; welcomed in are the celebrity and multi-billionaire visitors, whom Sarkozy greets while wearing expensive suits, stylish sunglasses and conspicuously large wristwatches. ${ }^{26}$

The French public did not necessarily want to share Sarkozy's personal life. They preferred to see him as the President of the Republic, the servant of the nation. Moreover, Sarkozy saw the media as an important ally which required constant drip-feeding. His initial popularity may have reinforced his illusory assumption that the public needed to see him constantly, irrespective of the issue. However, unlike Berlusconi, who had the luxury of owning the media, Sarkozy soon lost his public appeal and any control of the media agenda through his celebrity persona.

\section{Sarkozy as Conservative Populist}

Sarkozy was aware after Jean Marie Le Pen's first round victory in 2002 that the UMP had to take back the Front National vote to win power. His proposal for a "rupture", or a strong break with French traditional policiesechoed a word Le Pen had used about larger changes which could bring his party to power. ${ }^{27}$ In his use of the abusive term "racaile" for the summer rioters of 2005, mainly Beur males from poorer "cités" from housing blocks on the suburban outskirts of Paris, Sarkozy was playing the race/Islam or "fear" and crisis card which has been the staple of Right populist politics. In an era of French social malaise and of disillusionment with government and with the political parties and classes he, not Le Pen, would be the saviour of the nation. In 2007, the "strong" Sarkozy defeated his opponent, Ségolène Royale, through a combination of populism and celebrity (contemporary French has borrowed the English word "people" as a synonym for celebrities), as suggested by Patrick Charaudeau's analysis, entitled Entre populisme et peoplisme. ${ }^{28}$ In power, Sarkozy played the conservative populist card: in 2010 with his expulsion of the Roma, the gypsies who had entered France under Schengen and a crackdown on crime; and in a national identity debate led by the "Minister of Immigration, Integration, National Identity and Mutually-

\footnotetext{
${ }^{25}$ Libération, 'Bling Bling Président', Libération, 19 December 2007, Paris.

${ }^{26}$ Crumley, op.cit, p.1.

${ }^{27}$ J. Marcus, The National Front and French Politics: The Resistible Rise of Jean-Marie Le Pen, New

York University Press, New York, 1995, p.6.

${ }^{28}$ P. Charaudeau, Entre Populisme et Peopolisme: Comment Sarkozy a Gagné, Paris Vuibert, 2008.
} 
Supportive Development" (our translation). A ban on the niqab and the burqa, based on French constitutional laicity, followed in 2010-11, even though only about 2000 Muslim women wear such head coverings. He also played traditional presidential roles, expressing other French aspirations: French co-leadership of the European Union with Germany and a possible Mediterranean cluster of nations orchestrated by France. Unfortunately, for "Sarko", neither Right ("us and them") nor celebrity ("look at me") populism delivered continuing approval. In 2011, his popularity fell below that of Mme Marine Le Pen, the new leader of the Front National. Changing political positions and postures, and the global financial crisis, did not equate with the strong leadership he had promised in May 2007. Accusations of close relations with the rich, and of corruption, often accompany populist leaders in power. Sarkozy was tarnished by allegations concerning Liliane Bettencourt, the "L'Oréal heiress" fortune and illegal contributions to his election campaign, as his media and business connections further marked his fading image. "The Sarkozy and Carla Show", and the president, became, even more than other politicians, a cartoonists' delight, a small Punch and a large Judy, with the former shorn of presidential gravitas as well as physical stature. The "newcomer" of immigrant familial origins had not succeeded, either politically, by being more "patriotic" than other French citizens or, culturally, through his "nouveau" style of performance. His trajectory demonstrated that celebrities, and populists, can fall as rapidly as they have risen. This pattern is a third characteristic which populism and celebrity share as forms of performance.

Economic and political circumstances also underpinned the transition, In 2007, "Sarkozyisme" seemed a doctrine associated with neo-liberal, Thatcherite and/or Americophile embrace of change; it challenged European welfare and French state traditions. By 2011, after years of chameleon-like change and political opportunism, it stood for a president with an image and a celebrity wife but without policy. The relatively dull Socialist, Francois Hollande, defeated Sarkozy in the Presidential election, although his private life soon attracted unfriendly media and public attention.

\section{Silvio Berlusconi - "Mega-Celebrity" and Power}

After being forced to resign in 2011, and seeking re-election in 2013, Silvio Berlusconi continues to watch over a lacerated centre-right majority, which had, until recently, reluctantly endorsed the technocratic government under the economist, Mr Monti. To Berlusconi's wrath, Mario Monti stood in the February 2013 elections, offering an alternative centre-right platform to Berlusconi's own People's Freedom Party. What emerged from the elections, in a three way contest with the Social Democrats and Berlusconi's party, was the near "victory" of the Five Star Movement, a populist protest movement which exemplified anti-politics to its core. Italy has continued to be wracked by economic difficulties, political instabilities and problems and European complexities not tackled by the governments over several decades.The Schengen open borders within the EU and thousands of Tunisian refugees arriving in Italy, mostly bound for France, caused a rift between Italy and France, which halted onward trains from Italy. A joint media conference presented Nicolas Sarkozy, over-animated as always, beside the seemingly 
fixed, or perhaps botoxed, features of Prime Minister Silvio Berlusconi: France's "Punch" and a 74-year old Italian leader whose visage conjured images of Star Trek's "Mr. Spock". The "clash" between Sarkozy and Berlusconi seemed on the surface to be about immigration but greater issues lay behind these coded messages.

Between 2001 and 2006 and again from 2008-11, this "mogul from Milano" presided over Italy's longest political administration since World War II. Berlusconi's rise began as a self-made businessman who built and managed large building development projects around Milan in the 1970s. Alongside his publishing and insurance activities he developed media and television businesses, which became his most important political assets. His rise to prominence occurred during the last years of the so-called "First Republic" (1948-1992), in which the political spectrum had been dominated by the Christian Democrats, and to a lesser extent the Socialists. This era came to an abrupt end in 1992. ${ }^{29}$ Berlusconi saw this as an opportunity to enter politics and campaign for Prime Minister. Despite Berlusconi's rhetoric, including patriotic reasons for entering politics, some were suspicious that he could also use the office to help the Fininvest empire bail itself out of its debts. 30

In a few short months, he established his original political party, Forza Italia, its name a fusion of nationalist and populist tones, as well as the exclamatory slogan of the Italian national football team. Dominated by its leader, Berlusconi, the party's populist style reflected contemporary sporting nationalism. Berlusconi won a surprising victory in the 1994 elections, forming a coalition of centre-right political parties including the secessionist Northern League and the National Alliance party. In Berlusconi's first campaign he boasted about the need to "clean up the mess" left by the centreleft dominated governments of the early 1990s. He was also mindful that European integration was moving forward and that closer US relations required his personal attention.

The richest man in Italy, Berlusconi's political message was that he was in that position because of his belief in free enterprise and opposition to state welfare and involvement. This was sometimes presented in Cold War jargon in relation to his perennial fight against "communism". Berlusconi presented himself as smart businessman with many talents and a modicum of good luck, a caring father of the Italian clan writ large, ruthless saviour of the national economy and national prestige, and a naughty Italian male. ${ }^{31} \mathrm{His}$ first experience in government was short lived when political ally, the Northern League, defected from the coalition, placing the government in an untenable minority position. Finding himself again in opposition was a proving experience for Berlusconi who was used to getting his own way. Surprisingly, he remained leader of the opposition. After six years of weak and frail centre-

\footnotetext{
${ }^{29}$ B. Mascitelli, Corruption, Crisis and the End of the Cold War: Italy in the 1990s, Saarbrucken, Germany, Lambert Publishing, 2010.

$3^{\circ}$ G. Sartori, Il sultanato, Milano, Editori Laterza, 2010.

${ }^{31}$ P. Ginsborg, Silvio Berlusconi: Television, Power and Patrimony, London, Verso, 2004, A. Stille, The Sack of Rome: How a Beautiful European Country with a Fabled History and a Storied Culture Was Taken Over by a Man Named Silvio Berlusconi, The Penguin Press, New York, 2006.
} 
left governments, the Berlusconi centre-right opposition re-formed to win the 2001 elections and rule until 2006. Berlusconi then lost a knife-edge election to Romano Prodi by a mere 25,000 votes, controversially refusing to concede for weeks after the poll. The Romano Prodi centre-left coalition was so large and unstable that its political life would be short. Barely 18 months later, in April 2008 Italy again went to the polls. Berlusconi won easily and he governed comfortably until the crisis of 2010-11.

Berlusconi's political approach to politics, while successful, has been accompanied by a minefield of obstacles, as he gathered adversaries from many parts of society. The most troubling for him were the investigating magistrates who continue to investigate his business practices; allegations of bribery, tax evasion, collusion with the mafia and a host of other charges, involving the allegation that he sought to place his private interests at odds with his position as Prime Minister. Berlusconi's message to Italy presents a self-image of the lonely, honest, responsive and eternally young outsider. His self-description was challenged by many in Italy, and by more internationally. Nonetheless he continued to dominate television (his own stations and the public RAI) and ensured that his loyal newspapers printed "the news that is fit to print". Berlusconi was not just a media hoarder; he shrewdly created divisions amongst his opponents, espoused nationalism with no remorse about the nation's fascist past and, without shame, picked new and useful friends such as Vladimir Putin. Berlusconi was not embarrassed to put the European Union on guard with his sometimes veiled and sometimes explicit criticisms.

The most significant aspect of Berlusconi's leadership has been not so much the policies and vision but the populist themes associated with his style of government. His innate dislike for political parties meant that he commanded the government primarily through personal loyalty to him; many of his followers were his former company directors. Berlusconi rarely tolerated or invited open discussion. Few, or often none, would dare contest his views on policies and their operational consequences. On many occasions he expressed his contempt for the parliament and the political system. He prefers to address the people directly, often through television. His constant attack against Italian institutions, particularly the magistrates, indicates a "bartering mentality" whereby he wants to get his way through deals. He showed little concern for the rules and in many respects he believed his mandate allowed him to make the rules, ensuring his shock at his November 2011 demise

Berlusconi's case is unique as he had not faced a leadership crisis or challenge in office, despite simmering corruption allegations which he avoided through devious parliamentary and legal manoeuvres. In his last government his hold on his majority continued to weaken and cracks emerged. In 2010, Speaker of the House and long-time ally and supporter, Gianfranco Fini, broke with Berlusconi and his coalition, opening up the first serious fracture in the centre-right coalition which had maintained Berlusconi in power. Votes of confidence in December 2010 and again in June 2011 saw Berlusconi scrape through with reduced majorities. Genuine doubts gradually arose regarding Berlusconi's ability to continue to lead the centre-right, including an increasing threat of a defection of smaller parties. 
"Celebrity politician" only begins to describe the persona of Berlusconi. He is the personification of the mega-celebrity. Much of what he does makes him the centre of attention, the maker of the rules, the one who decides what happens. The celebrities came to him. Berlusconi's view is that, as a self-made man who has created conditions for which many should thank him, he is above most rules and institutions. He provided work and employment and has generated vast sums of wealth. In Italian terms, he has been viewed as the padrone and many Italians feel they need to submit to this status. As aptly concluded by Italian political observer, Matt Frei: "Whatever happens to him now, his legacy is that he has reinvented a corporate style of politics"32Arguably, it transcends celebrity and populist politics even as it embodies them.

Prominent political scientist Giovanni Sartori described the forms of Berlusconi dominance as akin to a "sultanate":

... il cavaliere [Berlusconi] has a sultanate with a party purely nominal which truly prostrates itself at his feet. He nominates ministers as he wishes, removes who he wishes, as though they were casually employed. No one breathes a word. The ministers of the party are his property and are such for favours rendered. And they are sent packing without even a groan if the boss decides as much. Nor is there within his government any lack of harem of beautiful women. The Sultanate was pretty much this. 33

While "Sultanate" is a colourful description of the relationship between Berlusconi and his close political periphery, it graphically describes the control and submissive behaviour of those around him and his desire to have beautiful, though not necessarily adept women, in his entourage. A concept parallel to "Sultan" might be mainstream, rather than marginal, "populist leader" coupled with celebrity, even given Berlusconi's unique dominance and the convergence of his media, business and political activities. However, sultans, like prime ministers, presidents, dictators, and celebrities, can fall.

\section{Conclusion}

The recurring media story of celebrities is of their rise to fame and then their subsequent fall through scandals, affairs, substance abuse or divorce, especially in the Hollywood theatre of celebrity. That double-edged sword may be significant for politicians during the inevitable vicissitudes of their political career. As in populism the narrative is as much about fall as it is about the rise.

While the growth of so-called "Americanisation" may be shorthand for celebrity politics, this phenomenon was nascent in French politics even before Sarkozy. The extent to which this new form of politics via celebrity status will define new political leaders is still unknown. Our two examples illustrate

${ }^{32}$ M. Frei, Berlusconi's reinvention of Italian politics, BBC Online, 13 December 2010, <http://www.bbc.co.uk/blogs/thereporters/mattfrei/2010/12/berlusconis_reinvention_of_ita.html>, accessed 11 July 2013.

33 Sartori, op. cit., p. xi - authors' translation. 
different forms of celebrity, each taking on aspects of populism and celebrity but with no clearly defined label. The cases of France and Italy, like their histories, share some common facets, but are distinct. It is beyond question that all contemporary politicians in Europe and the United States, trend towards celebrity styles of communication and seek media domination; and as a corollary to this public discourse is being supplanted by entertainment culture34 Initially Sarkozy turned celebrity to his political advantage. He injected celebrity into the conservative side of French politics. This may have ended the tradition of respect for the privacy of French politicians.

The Italian example is less clear in its outcome and celebrity status. Central to Berlusconi's self-styled status was his belief that he could be Italy's saviour. He believed that only he could save Italians from communism and from a state-infested and bureaucratic system. Berlusconi had political and economic power. and to a certain extent had little need to gravitate towards the social circles of celebrities. Even as his legitimacy attracted legal and public scrutiny in Italy, celebrities kow-towed to him and his media empire to secure popularity and favours. In contrast to Sarkozy, Berlusconi held the status of celebrity without deliberately $\mathrm{r}$ seeking it out. Arguably, these two individuals differ in nature rather than degree. While Sarkozy played celebrity and populist roles on the French party political stage, Berlusconi, the playwright and entrepeneur, still seeks to write and stage a play in his own genre of political performance. In each case, recent events have suggested how the dramas will end. In 2012-13, in what seem like coronial inquiries, Berlusconi still faces court on charges regarding alleged sex with minors at his bunga bunga parties, while corruption allegations surround his People of Freedom party continue. In June 2013, verdicts of guilt were reached in the case involving sexual relations with a minor and abuse of public office, regarding the bunga bunga parties, at the same time as a tax evasion case continued before the Court of Cassation. The former verdicts are subject to appeal and Berlusconi's advanced age ensures that he will not be sent to jail (despite a sentence of seven years), although both cases may lead to a bar on participation in public life. Despite an earlier 2013 renaissance, winning considerable support in the February elections, and his acquisition of a new love, a future wife younger than his youngest daughter, the scenario of a return to his previous style of ruling Italy is fanciful. The populist label has been captured by the protest Five Star Movement which, despite the novelty of its leader being a comedian, is, in a classical sense, anti-politics par excellence. In France, the Bettencourt illegal donations court case continues with Nicolas Sarkozy as a principal defendant. Perhaps the courts will pass their own specific final judgments on the gap between the celebrity populist styles of Berlusconi and Sarkozy and what they, and their governments, actually delivered. Only in retrospect, however, after the final curtain has fallen on their political/celebrity and public careers, will the audience know whether they have been watching an epic, a tragedy or a farce, for them and for their nation.

34 L. van Zoonen, Entertaining the Citizen: When Politics and Popular Culture Converge, Rowman and Littlefold, Lanham, MD, 2005. 